CURRENT

Jurnal Kajian Akuntansi dan Bisnis Terkini

https://current.ejournal.unri.ac.id

CURRENT

JC

hitps:/current.ejournal.unriac.id

\title{
PENGARUH DEWAN KOMISARIS INDEPENDEN, KEPEMILIKAN INSTITUSIONAL DAN INTELLECTUAL CAPITAL TERHADAP KINERJA KEUANGAN PERUSAHAAN
}

Fatimah Fatimah $^{1}$, Putri Dwi Wahyuni ${ }^{2}$ *

${ }^{123}$ Program Studi Akuntansi, Fakultas Ekonomi dan Bisnis, Universitas Mercu Buana, Jakarta

*E-mail: putri.dwi@mercubuana.ac.id

\begin{tabular}{l}
\hline Keywords \\
\hline Independent Board of \\
Commissioners, \\
Institutional \\
Ownership, \\
Intellectual Capital, \\
Net Profit Margin
\end{tabular}

Article Information

Received:

2020-11-20

Accepted:

2020-11-29

Available online:

2020-11-30

\begin{abstract}
This study aimed to determine the effect of Independent Board of Commissioners, Institutional Ownership and Intellectual Capital on Company's Financial Performance in Transportation Service companies listed on the Indonesia Stock Exchange in the period 2016 2018. The Company's financial performance is proxied by NPM (Net Profit Margin). This study uses multiple linear analysis methods with hypothesis testing the coefficient of determination, $f$ test and $t$ test. Based on the purposive sampling method, there is the final data in this study. The results of this study indicate that the Independent Board of Commissioners and Intellectual Capital don't have a significant effect on the Company's Financial Performance (NPM), while Institutional Ownership has a significant effect on the Company's Financial Performance (NPM).
\end{abstract}

\section{PENDAHULUAN}

Ariantini et al., (2017) menyatakan bahwa "Tujuan akhir yang ingin dicapai dalam suatu perusahaan adalah memperoleh laba atau keuntungan yang maksimal dengan meningkatkan efisiensi dan efektivitas perusahaan. Di tengah persaingan global yang semakin kompetitif, maka perusahaan saling meningkatkan daya saing di berbagai sektor untuk dapat menarik minat para investor untuk berinvestasi. Oleh karena itu, kinerja perusahaan harus ditingkatkan guna mempengaruhi persepsi investor terhadap perusahaan, tidak hanya pada kinerja perusahaan saat ini namun juga pada prospek perusahaan di masa depan. Setiap organisasi, sektor privat maupun publik, harus memiliki keunggulan kompetitif (competitive advantage) tertentu dibandingkan dengan organisasi lainnya."

Fenomena yang terjadi belakangan ini pada sektor transportasi adalah PT Garuda Indonesia Tbk (GIAA). PT Garuda Indonesia dianggap melakukan akal-akalan penyajian laporan keuangan. Garuda Indonesia berhasil mencatatkan laba bersih di 2018 setelah sebelum 
INTELLECTUAL CAPITAL TERHADAP KINERJA KEUANGAN PERUSAHAAN

bertubi-tubi merugi. Namun itu karena adanya piutang yang diakui sebagai pendapatan.

Menurut Enny Sri Hartati Direktur Institute for Development of Economics and Finance (INDEF), Garuda Indonesia sebagai perusahaan publik sekaligus BUMN seharusnya berlaku transparan dan mementingkan good corporate governance (GCG). Jika melakukan hal semacam itu, dia khawatir citra perusahaan akan tercoreng. Itu akan menurunkan kepercayaan publik terhadap Garuda dan itu berpengaruh terhadap performance. (https://finance.detik.com).

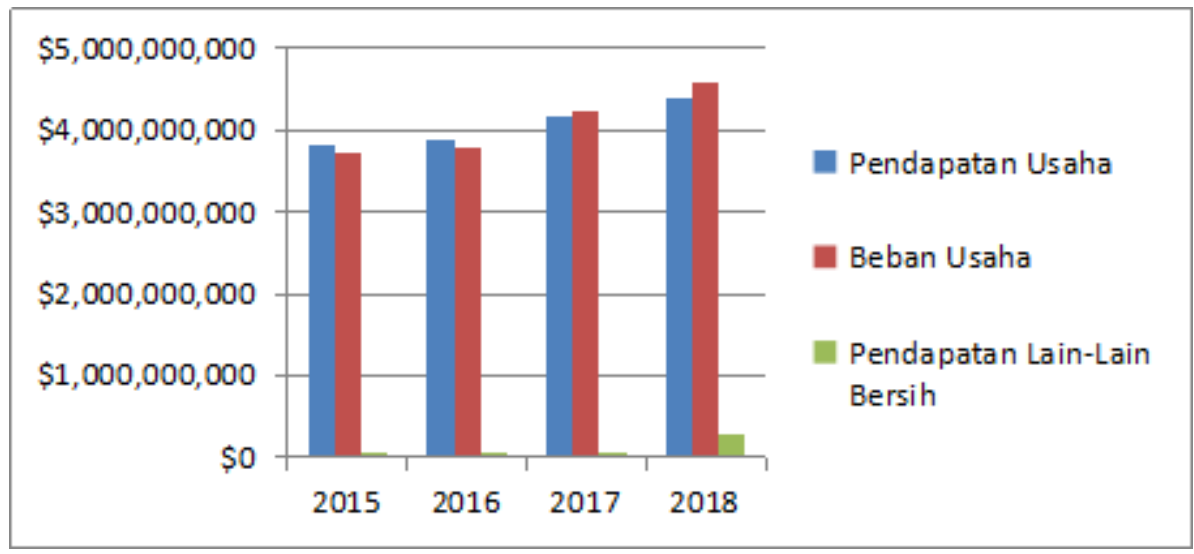

\section{Gambar 1}

Grafik Pendapatan dan Beban PT Garuda Indonesia

Sumber: Laporan Keuangan BEI di www.idx.co.id

Tabel 1

Tabel Laba Rugi PT Garuda Indonesia Periode 2015 - 2018

\begin{tabular}{crr}
\hline Tahun & Total Laba/Rugi Bersih & $\begin{array}{r}\text { Laba/Rugi Bersih Yang Didistribusikan } \\
\text { Kepada Pemilik Entitas Induk }\end{array}$ \\
\hline 2015 & $\$ 77,974,161$ & $\$ 76,480,236$ \\
2016 & $\$ 9,364,858$ & $\$ 8,069,365$ \\
2017 & $\$(213,389,678)$ & $\$(216,582,416)$ \\
2018 & $\$ 5,018,308$ & $\$ 809,846$ \\
\hline
\end{tabular}

Sumber: Laporan Keuangan BEI

Berdasarkan data dari Grafik 1 dan Tabel 1 diatas menunjukkan bahwa PT Garuda Indonesia mencatatkan keuntungan di 2015 sebesar USD 76,48 juta, dengan pendapatan usaha dan beban usaha sebesar USD 3,81 miliar dan USD 3,73 miliar serta pendapatan lain-lain bersih sebesar USD 70,32 juta. Tahun 2016 laba turun 89,45 persen menjadi USD 8,06 juta, dengan pendapatan usaha dan beban usaha naik tipis menjadi USD 3,86 miliar dan USD 3,79 miliar serta pendapatan lain-lain bersih menurun menjadi USD 50,28 juta. Kemudian tahun 2017 perseroan alami kerugian sebesar USD 216,58 juta, ini terjadi karena beban usaha naik 11,64 persen menjadi USD 4,23 miliar dan juga pendapatan usaha menjadi USD 4,17 miliar serta semakin menurunya pendapatan lain-lain bersih menjadi USD 19,79 juta. Sedangkan pada tahun 2018 perseroan drastis membukukan laba sebesar USD 809.846, Hal ini karena kenaikan pendapatan usaha menjadi sebesar USD 4,37 miliar dan beban usaha sebesar USD 4,57 miliar serta sangat meningkatnya pendapatan lain-lain bersih menjadi USD 278,81 juta. Kenaikan 
pendapatan lain-lain bersih tersebut karena adanya pengakuan piutang sebagai pendapatan lainlain sebesar USD 239.94 juta atas transaksi perjanjian kerjasama penyedia layanan konektivitas dalam penerbangan antara PT Mahata Aero Teknologi dengan PT Citilink selaku anak usaha PT Garuda Indonesia. Perjanjian ini ditandatangani tanggal 31 Oktober 2018 namun hingga tutup buku tahun 2018 belum adanya pembayaran dari pihak mahata, oleh sebab itu laporan keuangan menjadi sorotan karena adanya penolakan dua komisaris PT Garuda yaitu Chairal Tanjung dan Doni Oskaria untuk menandatangani laporan keuangan tahun 2018.

Demikian perlu adanya pengawasan terhadap kinerja manajemen sebagai pengelola bisnis dan pengambil keputusan di perusahaan agar apa yang diinginkan pemegang saham dapat terpenuhi dengan berdasarkan prinsip Good Corporate Governance yang berlaku. Prinsip-prinsip Good Corporate Governance yaitu keterbukaan (transparency), kewajaran (kesetaraan), akuntabilitas, pertanggungjawaban (responsibilitas), kemandirian (independensi). Dapat disimpulkan bahwa Good Coorporate Governance adalah suatu prinsip-prinsip yang diterapkan dengan baik pada perusahaan untuk meningkatkan kinerja keuangan, memaksimalkan nilai perusahaan dan meminimalisir adanya konflik kepentingan dalam perusahaan. Anggota dewan komisaris dan anggota dewan direksi diwajibkan untuk memenuhi berbagai persyaratan integritas, kompetensi, dan reputasi keuangan. Mekanisme GCG pada penelitian ini diproksi dengan proporsi komisaris independen dan kepemilikan institusional.

Aprianingsih \& Yushita (2016) menjelaskan bahwa "dewan komisaris adalah dewan yang memiliki peran sebagai pengawas jalannya perusahaan sesuai dengan prinsip GCG, keputusan yang diambil oleh perusahaan serta memberi nasihat kepada direksi. Dewan komisaris independen merupakan anggota dewan komisaris yang bersifat independen sehingga dapat melakukan pengawasan dan memberi nasihat kepada direksi secara objektif. Namun, pada kenyataannya dewan komisaris independen tidak menjalankan fungsinya dengan baik yang diakibatkan masih adanya hubungan afiliasi antar dewan komisaris sehingga kinerja dewan komisaris menjadi tidak independen".

Sama halnya dengan struktur kepemilikan saham, kepemilikan saham memiliki pengaruh yang cukup besar untuk penerapan good corporate governance. Puspitasari \& Ernawati (2010) menyatakan bahwa "jika kepemilikan saham terkonsentrasi, maka pengawasan terhadap pihak manajer akan lebih ketat. Selain itu, dengan adanya konsentrasi kepemilikan pada tingkat tinggi, maka keragaman kepentingan pemegang saham berkurang, sehingga kemungkinan terbentuknya kerja sama antara pihak manajer dan pemegang saham untuk meningkatkan nilai badan usaha semakin tinggi."

Menurut International Federation of Accountants (IFAC) dalam Lutfillah \& Sukmana (2018) mendefinisikan "intellectual capital sebagai sinonim dari intellectual property (kekayaan 
INTELLECTUAL CAPITAL TERHADAP KINERJA KEUANGAN PERUSAHAAN

intelektual), intellectual asset (aset intelektual), dan knowledge asset (aset pengetahuan), Modal ini dapat diartikan sebagai saham / modal yang berbasis pengetahuan yang dimiliki perusahaan. IFAC juga mengestimasikan bahwa saat ini nilai perusahaan lebih ditentukan atas manajemen atas intellectual capital, tidak lagi terhadap aset tetap." Sehingga, Intellectual capital masuk dalam kategori asset bukan modal (equity) di dalam neraca. Modal intelektual dapat mendorong kinerja keuangan perusahaan karena dapat menghasilkan nilai tambah sebagai suatu modal untuk bersaing dengan para kompetitornya, maka diharapkan dapat meningkatkan penjualan. Sumber daya perusahaan yang digunakan dengan efisien dapat memperkecil biaya-biaya yang terjadi. Semakin tinggi modal intelektual yang dimiliki maka laba semakin meningkat.

Menurut Abidin dalam Ulum MD (2009:3) menyatakan bahwa "perusahaan di Indonesia cenderung menggunakan conventional based (padat karya) sehingga produk yang dihasilkan masih belum banyak memanfaatkan teknologi." Menurut Pramelasari (2010) dalam (Putri \& Nuzula, 2019) menjelaskan bahwa "perusahaan-perusahaan di Indonesia secara umum masih menggunakan akuntansi tradisional yang menekankan pada penggunaan aset berwujud, sehingga laporan keuangan tradisional tidak mampu menyajikan informasi mengenai aset tidak berwujud secara keseluruhan."

Penelitian terkait dewan komisaris independen, kepemilikan institusional, Intellectual Capital dan kinerja keuangan perusahaan telah diteliti oleh beberapa peneliti dan memperoleh hasil yang beragam. Penelitian Ruslim \& Santoso (2018) menyatakan bahwa pengujian secara parsial hanya variabel proporsi komisaris independen dan kepemilikan saham institusional yang memiliki pengaruh signifikan positif terhadap kinerja keuangan perusahaan. Hasil penelitian ini bertentangan dengan Hasibuan \& Sushanty (2018) dan Gurdyanto \& Anita (2019) yang menyatakan tidak terdapat pengaruh antara Dewan Komisaris Independen terhadap Kinerja Keuangan. Maka dapat disimpulkan bahwa jumlah anggota dewan komisaris independen yang lebih banyak kurang dapat memungkinkan perusahaan mendapatkan kinerja yang lebih tinggi.

Penelitian selanjutnya dilakukan oleh Lestari \& Juliarto (2017) meneliti Pengaruh Dimensi Struktur Kepemilikan Terhadap Kinerja Perusahaan Manufaktur. Kepemilikan institusional memiliki pengaruh signifikan positif terhadap kinerja perusahaan. Maka dapat disimpulkan bahwa dengan adanya kepemilikan institusional dapat meningkatkan pengawasan terhadap manajer agar manajer berusaha meningkatkan kinerjanya agar sesuai dengan tujuan perusahaan. Penelitian (Nugroho \& Widiasmara, 2019) dan (Gurdyanto \& Anita, 2019) mendapatkan hasil bahwa kepemilikan institusional tidak memiliki pengaruh signifikan terhadap kinerja keuangan perusahaan. Hal tersebut kemungkinan disebabkan karena semakin banyaknya saham yang dimiliki pihak institusi/pemerintah, dengan ini kekuasaan pemerintah dalam mengendalikan perusahaan semakin besar sedangkan kekuasaan/kewenangan pihak 
manajemen dalam mengatur perusahaan akan semakin kecil sehingga menjadikan kinerja keuangan perusahaan semakin buruk.

Penelitian Sriwahyuni et al., (2019) yang meneliti Pengaruh Intellectual Capital Terhadap Kinerja Keuangan Perusahaan Farmasi di Indonesia. Kinerja keuangan pada penelitian ini diproksi dengan Return On Asset (ROA) dan Net Profit Margin (NPM). Dalam penelitian ini mendapatkan hasil bahwa intellectual capital (IC) memiliki pengaruh signifikan terhadap variabel kinerja keuangan Return On Assets (ROA) dan intellectual capital (IC) memiliki pengaruh terhadap variabel kinerja keuangan Net Profit Margin (NPM). Dan Penelitian yang dilakukan oleh Febriany (2019) juga menghasilkan bahwa Intellectual Capital memiliki pengaruh terhadap Kinerja Keuangan Perusahaan. Semakin tingginya Intellectual Capital perusahaan, maka semakin tinggi kinerja keuangan yang akan dicapai perusahaan. Hasil ini bertentangan dengan (Putri \& Nuzula, 2019) dan (Arifulsyah \& Nurulita, 2020) yang menghasilkan bahwa tidak ada pengaruh yang signifikan antara intellectual capital terhadap kinerja keuangan. Hal ini dapat membuktikan bahwa IC yang semakin baik dan semakin memadai, belum jaminan bisa meningkatkan kinerja keuangan perusahaan. Karena IC tanpa sistim pengendalian internal yang baik, pengelolaan sumber daya yang dimilikinya tidak akan berhasil dengan baik, sehingga dibutuhkan variabel penguat lainnya.

Terdapat 3 rumus masalah dalam penelitian ini: Pertama, mengetahui seberapa besar Dewan Komisaris Independen berpengaruh terhadap Kinerja Keuangan. Kedua, mengetahui seberapa besar Kepemilikan Institusional berpengaruh terhadap Kinerja Keuangan. Ketiga, seberapa besar Intellectual Capital berpengaruh terhadap Kinerja Keuangan.

\section{PENGEMBANGAN HIPOTESIS}

\section{Pengaruh Dewan Komisaris Independen terhadap Kinerja Keuangan}

Menurut Jensen \& Meckling (1976) Teori keagenan adalah teori yang menjelaskan tentang hubungan antara principal dan agent. Principal adalah pemilik atau pemegang saham, sedangkan agent adalah orang yang diberi kuasa oleh principal yaitu manajemen yang mengelola perusahaan. Hubungan antara teori keagenan dengan kinerja perusahaan adalah dimana manajemen sebagai para pengelola bisnis di perusahaan, mengusahakan agar profit dari perusahaan terlihat baik secara laporan keuangan. Hal tersebut untuk meyakinkan para stakeholder mengenai kinerja manajemen sudah efektif.

Dalam penelitian Ruslim \& Santoso (2018) menyatakan bahwa pengujian secara masing-masing variabel hanya variabel proporsi komisaris independen dan kepemilikan saham institusional yang memiliki pengaruh signifikan positif terhadap kinerja keuangan perusahaan. Sependapat dengan penelitian Prayanthi \& Laurens (2020) yang menyatakan bahwa Proporsi 
INTELLECTUAL CAPITAL TERHADAP KINERJA KEUANGAN PERUSAHAAN

komisaris independen memiliki pengaruh signifikan terhadap kinerja keuangan (ROE). Maka dapat disimpulkan bahwa semakin banyak jumlah Komisaris Independen, maka semakin tinggi independensi yang ada dalam dewan komisaris.

Hubungan antara komisaris independen dan kinerja keuangan juga didukung oleh perspektif bahwa dengan adanya komisaris independen diharapkan dapat memberikan fungsi pengawasan terhadap perusahaan secara objektif dan independen, menjamin pengelolaan yang bersih dan sehatnya operasi perusahaan sehingga dapat mendukung kinerja perusahaan (Elisetiawati \& Artinah, 2016). Berdasarkan penjelasan tersebut maka hipotesis yang diajukan sebagai berikut.

\section{$\mathrm{H}_{1}$ : Dewan Komisaris Independen berpengaruh terhadap Kinerja Keuangan.}

\section{Pengaruh Kepemilikan Institusional terhadap Kinerja Keuangan}

Menurut Jensen \& Meckling (1976) terdapat hubungan positif antara kepemilikan institusional terhadap kinerja keuangan perusahaan. Penelitian (Pricilia \& Susanto, 2017) menyatakan bahwa "kepemilikan institusional memiliki arti penting dalam memonitor manajemen karena dengan adanya kepemilikan oleh institusional akan mendorong peningkatan pengawasan yang lebih optimal. Monitoring tersebut tentunya akan menjamin kemakmuran untuk pemegang saham, pengaruh kepemilikan institusional sebagai agen pengawas ditekan melalui investasi mereka yang cukup besar dalam pasar modal.”

Dalam penelitian yang dilakukan oleh Ruslim \& Santoso (2018) menyatakan bahwa pengujian secara masing masing variabel hanya variabel proporsi komisaris independen dan kepemilikan saham institusional yang memiliki pengaruh signifikan dengan arah positif terhadap kinerja keuangan perusahaan. Sependapat dengan penelitian Lestari \& Juliarto (2017) bahwa kepemilikan institusional memiliki pengaruh signifikan positif terhadap kinerja perusahaan dengan arah positif. Semakin kuat pengendalian terhadap perusahaan maka akan semakin tinggi pula kepemilikan institusional terhadap perusahaan, kinerja perusahaan akan naik apabila pemilik perusahaan bisa mengendalikan perilaku manajemen supaya bertindak sesuai tujuan perusahaan. Berdasarkan penjelasan tersebut maka hipotesis yang diajukan sebagai berikut.

\section{$\mathrm{H}_{2}$ : Kepemilikan Institusional berpengaruh terhadap Kinerja Keuangan.}

\section{Pengaruh Intellectual Capital terhadap Kinerja Keuangan}

Menurut Dowling \& Pfeffer (1975) dalam teori legitimasi menjelaskan bahwa “organisasi dapat menyesuaikan output, tujuan, dan metode operasi agar sesuai dengan definisi legitimasi yang berlaku dan organisasi dapat mencoba, melalui komunikasi, untuk mengubah 
definisi legitimasi sosial sehingga sesuai dengan praktik, output, dan nilai-nilai organisasi saat ini. Legitimasi melibatkan perubahan dalam misi organisasi atau penggunaan simbol untuk mengidentifikasi organisasi dengan lembaga atau praktik sosial yang sah.”

Dalam buku Intellectual Capital: Model Pengukuran, Framework Pengungkapan \& Kinerja Organisasi, Ulum (2017:40) menjelaskan bahwa "teori legitimasi sangat erat hubungannya dengan pelaporan IC dan juga erat hubungannya dengan penggunaan metode content analysis sebagai ukuran dari pelaporan tersebut. Perusahaan cenderung untuk melaporkan IC jika mereka memiliki kebutuhan khusus untuk melakukannya. Hal ini mungkin terjadi jika perusahaan tersebut tidak mampu melegitimasi statusnya berdasarkan tangible assets yang umumnya dikenal sebagai simbol kesusksesan perusahaan."

Sriwahyuni et al., (2019) dalam uji hipotesisnya menghasilkan "bahwa Intellectual Capital secara signifikan memiliki pengaruh terhadap variabel Kinerja Keuangan yang diproksikan terhadap ROA (Return On Assets). Adanya pengaruh antara IC dengan ROA dikarenakan perusahaan lebih memaksimalkan pemanfaatan asetnya untuk mendorong kualitas karyawan yang dimiliki untuk meningkatkan laba yang dihasilkan. Intellectual Capital secara signifikan berpengaruh terhadap variabel Kinerja Keuangan yang diproksikan terhadap NPM (Net Profit Margin). Dapat diartikan bahwa Intellectual Capital dalam perusahaan mempengaruhi kinerja keuangan perusahaannya. Hal ini dapat disebabkan karena jumlah beban tenaga kerja merupakan sebagian besar dari total beban perusahaan. Sedangkan net profit margin diperoleh dari laba bersih dibandingkan dengan penjualan.”

Dalam penelitian yang dilakukan oleh Puspitosari (2016), juga menghasilkan pengaruh intellectual capital yang positif terhadap kinerja keuangan, Ketiga komponen modal intelektual mempunyai pengaruh positif signifikan terhadap ROA. Namun dari ketiga komponen, VACA memiliki pengaruh paling kuat dibandingkan dengan STVA dan VAHUnya yang berarti industri perbankan di Indonesia masih lebih mengandalkan modal fisiknya. Kontribusi human capital terhadap kinerja keuangan perusahaan masih belum sekuat kontribusi modal fisiknya. Berdasarkan uraian tersebut maka hipotesis yang diajukan sebagai berikut..

\section{$\mathrm{H}_{3}$ : Intellectual Capital berpengaruh terhadap Kinerja Keuangan.}

\section{METODE PENELITIAN}

\section{Jenis Penelitian}

Jenis dalam penelitian ini menggunakan penelitian kausal yang bertujuan untuk menganalisa bagaimana suatu variabel mempengaruhi variabel lainnya. Menurut Sugiyono (2014:42) menjelaskan bahwa "penelitian kausal yaitu hubungan yang bersifat sebab akibat dengan tujuan untuk mendapatkan bukti hubungan sebab akibat sehingga dapat diketahui mana 
INTELLECTUAL CAPITAL TERHADAP KINERJA KEUANGAN PERUSAHAAN

yang menjadi variabel yang mempengaruhi dan mana variabel yang dipengaruhi yaitu untuk

menguji hipotesis tentang pengaruh satu atau beberapa variabel terhadap variabel lainnya."

\section{Populasi dan Sampel}

Populasi dalam penelitian ini adalah perusahaan-perusahaan jasa transportasi yang terdaftar di BEI terdapat 46 perusahaan yang terdaftar di BEI selama tahun 2016 - 2018. Berdasarkan metode pengambilan sampel diperoleh sebanyak 34 perusahaan jasa transportasi yang sesuai dengan kriteria purposive sampling, namun pada saat dilakukan pengujian, terdapat 16 perusahaan yang memiliki nilai data ekstrim atau nilai data yang jauh berbeda dari periode sebelumnya yang menyebabkan hasil pengujian tidak signifikan. Sehingga diputuskan untuk mengesampingkan 16 perusahaan tersebut dalam penelitian ini.

\section{Tabel 2}

Kriteria Pengambilan Sampel Penelitian dengan Data Outlier

\begin{tabular}{cc}
\hline Kriteria & Total \\
\hline Perusahaan Jasa Transportasi yang terdaftar di Bursa Efek Indonesia periode tahun & 46 \\
$2016-2018$ & \\
Dikurangi: & $(2)$ \\
1. Perusahaan yang tidak lengkap laporan keuangannya tahun 2016-2018 & $(10)$ \\
2. Perusahaan yang listing setelah tahun penelitian 2016-2018 & 34 \\
Jumlah Sampel yang diteliti & 3 \\
Tahun pengamatan & $\mathbf{1 0 2}$ \\
Jumlah keseluruhan sampel dalam penelitian (34 x 3) & 16 \\
Data Outlier & $\mathbf{8 4}$ \\
\hline
\end{tabular}

\section{Sumber Data dan Metode Pengumpulan Data}

Metode pengumpulan data dalam penelitian ini dilakukan dengan studi pustaka dan data arsip. Data sekunder yang digunakan pada penelitian ini didapat dari laporan tahunan (annual report) dan laporan keuangan (financial statement) perusahaan jasa sektor transportasi yang telah terdaftar di Bursa Efek Indonesia (BEI) pada periode tahun 2016 - 2018. Data laporan ini didapat melalui situs resmi Bursa Efek Indonesia (BEI) di www.idx.co.id.

\section{Definisi Operasional dan Pengukuran Variabel}

Pada penelitian ini ada dua variabel yang digunakan yaitu variabel independen dan variabel dependen. Variabel independennya adalah dewan komisaris independen, kepemilikan institusional dan intellectual capital sedangkan variabel dependennya adalah kinerja keuangan perusahaan.

\section{Variabel Dependen}

Variabel dependen dalam penelitian ini yaitu Kinerja Keuangan. Kinerja keuangan adalah suatu laporan keuangan perusahaan yang menunjukkan keadaan perusahaan dimana 
akan digunakan untuk bahan pertimbangan bagi perusahaan untuk melakukan tindakan selanjutnya maupun bagi masyarakat untuk menilai kelancaran perusahaan tersebut sebelum melakukan tindakan (Dewi et al., 2018).

Kinerja Keuangan diproksi Net Profit Margin (NPM) dengan rumusnya :

$\mathrm{NPM}=\quad \frac{\text { Laba bersih setelah pajak }}{\text { Penjualan Bersih }} \times 100 \%$

\section{Variabel Independen}

\section{Dewan Komisaris Independen}

Dalam penelitian Budyastuti (2018) menjelaskan bahwa "dewan komisaris independen merupakan anggota dewan komisaris yang tidak memiliki ikatan dengan manajemen perusahaan sehingga dengan adanya komisaris independen, fungsi pengawasan dan pengendalian yang dilakukan oleh dewan komisaris terhadap direksi diharapkan menjadi dapat lebih objektif dan seksama."

Rumus Proporsi Dewan Komisaris Independen :

Proporsi DKI =

$$
\sum \text { anggota komisaris Independen }
$$

$\sum$ anggota dewan komisaris

\section{Kepemilikan Institusional}

Dalam penelitian yang dilakukan oleh Putra \& Fidiana (2017) menjelaskan bahwa "kepemilikan institusional merupakan kepemilikan saham oleh pihak institusi lain yaitu kepemilikan oleh perusahaan atau lembaga lainnya. Kepemilikan saham oleh pihak-pihak yang terbentuk institusi seperti perusahaan asuransi, bank, perusahaan investasi, dan kepemilikan institusi lain."

Rumus Kepemilikan Institusional :

Kepemilikan Institusional $=$

$\sum$ Saham yang Dimiliki Institusional

\section{Intellectual Capital}

$$
\sum \text { Saham yang beredar }
$$

Menurut Roos \& Roos (1997) Intellectual Capital merupakan kumpulan aset tersembunyi yang dimiliki organisasi, seperti brands, trademarks dan patents serta aset lainnya yang tidak nampak pada laporan keuangan. Intellectual Capital merupakan sumber daya penting bagi organisasi untuk mempertahankan keunggulan kompetitif (Ulum, 2017:80).

Intellectual Capital, pengukurannya dengan metode MVAIC diawali dengan perhitungan VA sebagai titik awal. 


$$
\text { VA }=\text { OUT }-\mathbf{I N}
$$

OUT $=$ total penjualan dan pendapatan lain

IN = beban penjualan dan biaya-biaya lain kecuali beban karyawan.

Lalu dilanjutkan dengan menghitung komponen - komponen Intellectual Capital.

Human Capital Efficiency (HCE)

Dalam buku Intellectual Capital: Model Pengukuran, Framework Pengungkapan \& Kinerja Organisasi, Ulum (2017:121) menyatakan bahwa "HCE digunakan untuk menunjukkan berapa banyak VA yang dapat dihasilkan dengan dana yang dikeluarkan untuk tenaga kerja.” Formula untuk menghitungnya adalah (Ulum, 2017:124):

$$
\mathrm{HCE}=\frac{\mathrm{VA}}{\mathrm{HC}}
$$

Keterangan:

HCE = Human Capital Efficiency (Rasio dari VA terhadap HC)

$\mathrm{VA}=$ Value Added

$\mathrm{HC}=$ Human Capital (Total salaries and wages; beban karyawan)

\section{Structural Capital Efficiency (SCE)}

Dalam buku Intellectual Capital: Model Pengukuran, Framework Pengungkapan \& Kinerja Organisasi, Ulum (2017:121) menyatakan bahwa "SCE digunakan untuk mengukur jumlah SC yang dibutuhkan untuk menghasilkan satu rupiah dari VA dan merupakan indikasi bagaimana keberhasilan SC dalam penciptaan nilai." Formula untuk menghitungnya yaitu (Ulum, 2017:124):

$$
\mathrm{SCE}=\frac{\mathrm{SC}}{\mathrm{VA}}
$$

Keterangan :

SCE = Structural Capital Efficiency (Rasio dari VA terhadap SC)

$\mathrm{SC}=$ Structural Capital $(\mathrm{VA}-\mathrm{HC})$

$\mathrm{VA}=$ Value Added

\section{Relational Capital Efficiency (RCE)}

Dalam buku Intellectual Capital: Model Pengukuran, Framework Pengungkapan \& Kinerja Organisasi, Ulum (2017:125) menyatakan bahwa "RCE digunakan untuk melihat berapa banyak value added yang dihasilkan oleh perusahaan setiap satu rupiah yang diinvestasikan dalam biaya pemasaran. RC diproksikan dengan biaya pemasaran." RCE 
dihitung dengan formula sebagai berikut (Ulum, 2017:126):

$$
\mathbf{R C E}=\frac{\mathbf{R C}}{\mathrm{VA}}
$$

Keterangan:

$\mathrm{RCE}=$ Relational Capital Efficiency

$\mathrm{VA}=$ Value Added

$\mathrm{RC}=$ Relational Capital (Biaya pemasaran)

Capital Employed Efficiency (CEE)

Dalam buku Intellectual Capital: Model Pengukuran, Framework Pengungkapan \& Kinerja Organisasi, Ulum, (2017:121) menyatakan bahwa "CEE menunjukkan berapa banyak nilai tambah perusahaan yang dihasilkan dari modal yang digunakan." Efisiensi dari modal yang digunakan dapat diperoleh dengan cara sebagai berikut (Ulum, 2017:125):

$$
\mathrm{CCE}=\frac{\mathrm{VA}}{\mathrm{CE}}
$$

Keterangan:

$\mathrm{CEE}=$ Capital Employed Efficiency

$\mathrm{VA}=$ Value Added

$\mathrm{CE}=$ Capital Employed $($ Total aset $)$

Secara utuh, MVAIC diformulasikan sebagai berikut:

$\mathrm{MVAIC}=\mathrm{ICE}+\mathrm{CEE}$

$\mathrm{ICE}=\mathrm{HCE}+\mathrm{SCE}+\mathrm{RCE}$

Menurut Ulum (2008) dalam (Ulum, 2017:136), hasil perhitungan VAIC dapat diranking berdasarkan skor yang dimiliki. Dengan kategori sebagai berikut:

a. Top performers - skor VAIC diatas 3,00

b. Good performers - skor VAIC diantara 2,0 sampai 2,99

c. Common performers - skor VAIC diantara 1,5 sampai 1,99

d. Bad performers - skor VAIC dibawah 1,5

\section{Metode Analisis Data}

Pada penelitian ini data diolah menggunakan software SPPS 21 dengan analisis statistik sebagai berikut (Ghozali, 2016) :

Analisis Statistik Deskriptif

Statistik deskriptif memberikan gambaran atau deskripsi suatu data yang dilihat dari nilai rata-rata (mean), standar deviasi, varian, maksimum, minimum, sum, range, kurtosis, dan skewness (kemencengan distribusi). 
INTELLECTUAL CAPITAL TERHADAP KINERJA KEUANGAN PERUSAHAAN

\section{Uji Asumsi Klasik}

\section{Uji Normalitas}

Ghozali (2016:154) menjelaskan bahwa "Uji normalitas bertujuan untuk menguji apakah dalam model regresi, variabel pengganggu atau residual memiliki distribusi normal. Seperti diketahui bahwa uji t dan F mengasumsikan bahwa nilai residual mengikuti distribusi normal. Kalau asumsi ini dilanggar maka uji statistik menjadi tidak valid untuk jumlah sampel kecil. Pada penelitian ini akan digunakan uji Kolmogorov Smirnov merupakan merupakan pengujian normalitas yang banyak dipakai."

\section{Uji Multikolonieritas}

Ghozali (2016:103) menjelaskan bahwa "Uji multikolinieritas bertujuan untuk menguji apakah model regresi ditemukan adanya kolerasi antar variabel bebas (independen). Untuk mendeteksi Multikolonieritas dapat juga dilihat dari (1) nilai tolerance dan lawannya (2) variance inflation factor (VIF). Tolerance mengukur variabilitas variabel independen yang terpilih yang tidak dijelaskan oleh variabel independen lainnya. Jadi nilai tolerance yang rendah sama dengan nilai VIF tinggi (karena VIF $=1 /$ Tolerance). Nilai cutoff yang umum dipakai untuk menunjukkan adanya multikolonieritas adalah nilai Tolerance $<0.10$ atau sama dengan nilai VIF > 10.”

\section{Uji Heteroskedastisitas}

Ghozali (2016:134) menjelaskan bahwa "Uji heterokedastisitas bertujuan untuk menguji apakah dalam model regresi terjadi ketidaksamaan variance dari residual satu pengamatan ke pengamatan yang lain. Jika variance dari residual satu pengamatan ke pengamatan lain tetap, maka disebut Homoskedastisitas dan jika berbeda disebut Heteroskedastisitas."

\section{Uji Autokorelasi}

Ghozali (2016:107) menjelaskan bahwa "Uji autokorelasi bertujuan menguji apakah dalan model regresi linier ada korelasi antara kesalahan pengganggu pada periode t dengan kesalahan penggangu pada periode t-1 (sebelumnya). Jika terjadi korelasi, maka dinamakan ada problem autokorelasi. Autokorelasi muncul karena observasi yang berurutan sepanjang waktu berkaitan satu sama lainnya." Model regresi yang baik adalah regresi yang bebas dari autokorelasi. Cara untuk mendeteksi ada atau tidaknya autokorelasi adalah dengan menggunakan uji durbin - watson (DW test).

\section{Uji Hipotesis}

\section{Koefisien Determinasi}


Ghozali (2016:95) menjelaskan bahwa "Koefisien determinasi $\left(\mathrm{R}^{2}\right)$ pada intinya mengukur seberapa jauh kemampuan model dalam menerangkan variasi variabel dependen. Nilai koefisien determinasi adalah antara nol dan satu. Nilai $\mathrm{R}^{2}$ yang kecil berarti kemampuan variabel-variabel independen dalam menjelaskan variasi variabel dependen amat terbatas. Nilai yang mendekati satu berarti variabel-variabel independen memberikan hampir semua informasi yang dibutuhkan untuk memprediksi variasi variabel dependen.”

Uji Kesesuaian Model (ANOVA-Uji F)

Ghozali (2016:171) menjelaskan bahwa "Uji F digunakan untuk mengetahui apakah variabel independen secara bersama-sama atau simultan mempengaruhi variabel dependen." Uji statistik F dapat disebut juga tentang kebaikan model regresi (goodness of fit).

\section{Uji Statistik T (Uji Hipotesis)}

Dalam buku Aplikasi Analisis Multivariate dengan Program IBM SPSS 21, Ghozali (2016:171) menjelaskan :

"Uji parsial pada digunakan untuk mengetahui pengaruh masing-masing variabel independen terhadap variabel dependen."

\section{Analisis Regresi Linier Berganda}

Ghozali (2016:94) menjelaskan bahwa "Analisis regresi digunakan untuk mengukur kekuatan hubungan antara dua variabel atau lebih, juga menunjukkan arah hubungan antara variabel dependen dengan variabel independen."

Model persamaan regresi yang diuji pada penelitian ini adalah :

$$
\mathrm{NPM}=\alpha+\beta 1 \mathrm{DKI}+\beta 2 \mathrm{INST}+\beta 3 \mathrm{MVAIC}+\mathrm{e}
$$

\section{HASIL PENELITIAN DAN PEMBAHASAN}

\section{Uji Statistik Deskriptif Setelah Eliminasi Outlier}

Hasil Uji Statistik Deskriptif pada penelitian ini disajikan pada Tabel 3 berikut:

\section{Tabel 3}

\section{Uji Statistik Deskriptif Setelah Eliminasi Outlier}

\begin{tabular}{|c|c|c|c|c|}
\hline Variabel & Minimum & Maximum & Mean & Std. Deviasi \\
\hline Net Profit Margin & -77.75 & 36.46 & -8.39 & 28.38 \\
\hline $\begin{array}{ll}\text { Dewan } & \text { Komisaris } \\
\text { Independen } & \end{array}$ & 20.00 & 66.67 & 39.96 & 10.00 \\
\hline Kepemilikan & 0.00 & 100 & 63.46 & 25.00 \\
\hline $\begin{array}{l}\text { Intellectual Capital } \\
\text { Data Observasi }\end{array}$ & -3.45 & 28.85 & 2.34 & 3.55 \\
\hline
\end{tabular}

Sumber: Olah Data dengan menggunakan SPSS

Nilai rata-rata kinerja keuangan (NPM) sebesar -8,39 hal ini menunjukkan bahwa 
INTELLECTUAL CAPITAL TERHADAP KINERJA KEUANGAN PERUSAHAAN

manajemen perusahaan jasa transportasi tidak mampu dalam mengelola stabilitas penjualan jasa untuk meningkatkan pendapatan. Nilai rata-rata DKI sebesar 39,9644\% artinya perusahaan jasa transportasi dalam penelitian ini telah mempunyai komisaris independen yang sudah sesuai syarat dalam peraturan otoritas jasa keuangan Nomor 33/POJK.04/2014 tentang perusahaan wajib memiliki Komisaris Independen dengan komposisi minimal 30 persen dari total anggota Dewan Komisarisnya. INST memiliki nilai rata-rata sebesar 63,45 atau sebesar 63,45\% ratarata proporsi kepemilikan saham yang dimiliki sebuah institusi pada perusahaan sampel penelitian ini dan dapat disimpulkan bahwa rata-rata pengambilan keputusan perusahaan dikendalikan penuh oleh pemegang saham yang merupakan institusi dikarenakan rata-rata kepemilikan sahamnya diatas 50\%. Nilai rata-rata IC sebesar 2,34 maka masuk ke dalam kategori Good performers berdasarkan ranking yang dirancang oleh Ulum (2008) dalam (Ulum, 2017), artinya perusahaan-perusahaan telah melakukan pengelolaan modal intelektualnya dengan baik.

\section{Uji Asumsi Klasik Setelah Eliminasi Outlier}

Hasil Uji Normalitas penelitian ini disajikan pada Tabel 4 :

\section{Tabel 4}

\section{Uji Normalitas Setelah Eliminasi Outlier}

\begin{tabular}{lc}
\hline & Unstandarized Residual \\
\hline Data Observasi & 84 \\
Kolmogorov - Smirnov Z & 0.97 \\
Asymp. Sig. (2-tailed) & 0.30 \\
Kesimpulan & Data berdistribusi normal $(0.30>0.05)$ \\
\hline Sumber: Olah Data dengan Mengounakan SPSS
\end{tabular}
Sumber: Olah Data dengan Menggunakan SPSS

\section{Uji Multikolinieritas}

Hasil Uji Multikolnieritas penelitian ini disajikan pada Tabel 5 :

\section{Tabel 5}

\section{Uji Multikolinieritas}

\begin{tabular}{ccc}
\hline Variabel & \multicolumn{2}{c}{ Collinearity Statistics } \\
& Tolerance & VIF \\
\hline DKI & 0.97 & 1.03 \\
INST & 0.97 & 1.03 \\
MVAIC & 0.99 & 1.01 \\
Kesimpulan & Semua variabel memiliki nilai tolerance $>0,1$ dan nilai \\
& VIF $<10$ yang berarti tidak terdapat korelasi antar variabel \\
& independen \\
\hline
\end{tabular}

Sumber: Olah Data dengan Menggunakan SPSS

Uji Heteroskedastisitas

Hasil Uji Heteroskedastisitas penelitian ini disajikan pada Tabel 6 :

\section{Tabel 6}


Uji Glejser - setelah diobati

\begin{tabular}{cc} 
Variabel & Signifikansi \\
\hline DKI & 0.78 \\
Invers_INST & 0.19 \\
MVAIC & 0.14 \\
Kesimpulan & Bebas Heteroskedastisitas (Nilai sig > 0.05) \\
\hline
\end{tabular}

Sumber: Olah Data dengan Menggunakan SPSS

Uji Autokorelasi

Hasil Uji Autokorelasi penelitian ini disajikan pada Tabel 7 :

Tabel 7

\section{Uji Autokorelasi}

\begin{tabular}{lc}
\multicolumn{1}{c}{ Variabel } & Durbin Watson \\
\hline Independen: MVAIC, DKI, INST & 2.145 \\
Dependen: NPM & \\
Kesimpulan & $\mathrm{du}<\mathrm{dw}<4$-du $(1.7199<2.145<2.280)$ \\
& Tidak terjadi autokorelasi \\
\hline
\end{tabular}

Sumber: Olah Data dengan Menggunakan SPSS

\section{Uji Hipotesis}

Koefisien Determinasi $\left(R^{2}\right)$

Hasil Uji Koefisien Determinasi $\left(\mathrm{R}^{2}\right)$ penelitian ini disajikan pada Tabel 8 :

\section{Tabel 8}

Koefisien Determinasi (R2)

\begin{tabular}{|c|c|}
\hline Variabel & Adjusted R Square \\
\hline Independen: DKI, INST, MVAIC & $16.40 \%$ \\
\hline \multicolumn{2}{|l|}{ Dependen: NPM } \\
\hline Kesimpulan & $\begin{array}{l}\text { Variabel independen (Dewan Komisaris Independen, } \\
\text { Kepemilikan Institusional dan Intellectual Capital) dapat } \\
\text { menerangkan variabel dependen (Net Profit Margin) } \\
\text { sebesar 16.40\%, sedangkan senilai } 83,6 \% \text { sisanya } \\
\text { diterangkan oleh variabel lain yang tidak diajukan dalam } \\
\text { model penelitian ini }\end{array}$ \\
\hline
\end{tabular}

Sumber: Olah Data dengan Menggunakan SPSS

Uji Kesesuaian Model (ANOVA - Uji F)

Hasil Uji Kesesuaian Model (ANOVA - Uji F) pada penelitian ini disajikan pada

Tabel 9 :

\section{Tabel 9}

Uji Kesesuaian Model (ANOVA - Uji F)

\begin{tabular}{ccc}
\hline Model & F hitung & Signifikan \\
\hline Regression & 6.433 & 0.001 \\
Kesimpulan & $0.001<0.05$ sehingga model penelitian ini layak untuk \\
& \multicolumn{2}{c}{ digunakan } \\
\end{tabular}

Sumber: Olah Data dengan Menggunakan SPSS

Hasil Pengujian Hipotesis 
Hipotesis diuji dengan menggunakan uji yang dapat dilihat pada tabel Tabel 10 :

Tabel 10

Uji Statistik T

\begin{tabular}{cccc}
\hline Variabel & T hitung & Signifikansi & Kesimpulan \\
\hline DKI & 0.222 & 0.825 & Hipotesis Ditolak \\
INST & 4.165 & 0.000 & Hipotesis Diterima \\
MVAIC & 0.728 & 0.469 & Hipotesis Ditolak \\
\hline
\end{tabular}

Sumber: Olah Data dengan Menggunakan SPSS

Hasil pengujian menunjukkan bahwa Dewan Komisaris Independen (DKI) memiliki nilai $\mathrm{T}$ hitung sebesar 0,222 dan nilai signifikansi sebesar 0,825. Hal ini dapat menjelaskan bahwa variabel Dewan Komisaris Independen tidak memiliki pengaruh signifikan pada taraf signifikansi 5\%. Dengan demikian hipotesis pertama ditolak dan menyatakan bahwa dewan komisaris independen tidak berpengaruh signifikan terhadap kinerja keuangan (NPM).

Kepemilikan Institusional (INST) memiliki nilai $\mathrm{T}$ hitung sebesar 4,165 dan nilai signifikansi sebesar 0,000. Hal ini dapat menjelaskan bahwa variabel Kepemilikan Institusional berpengaruh signifikan pada taraf signifikansi 5\%. Dengan demikian hipotesis kedua diterima dan menyatakan bahwa kepemilikan institusional berpengaruh signifikan terhadap kinerja keuangan (NPM).

Intellectual Capital memiliki nilai T hitung sebesar 0,728 dan nilai signifikansi sebesar 0,469. Hal ini dapat menjelaskan bahwa variabel Intellectual Capital tidak berpengaruh signifikan pada taraf signifikansi 5\%. Dengan demikian hipotesis ketiga ditolak dan disimpulkan bahwa intellectual capital tidak memiliki pengaruh signifikan terhadap Kinerja Keuangan (NPM).

\section{Pembahasan}

Pengaruh Dewan Komisaris Independen Berpengaruh Terhadap Kinerja Keuangan

Hasil pengujian hipotesis menjelaskan bahwa dewan komisaris independen tidak memiliki pengaruh signifikan terhadap kinerja keuangan (NPM) sehingga hipotesis pertama ditolak. Hasil penelitian ini sejalan dengan penelitian yang dilakukan oleh Hasibuan \& Sushanty (2018) yang menyatakan tidak terdapat pengaruh antara dewan komisaris independen terhadap kinerja keuangan. Hal ini menunjukkan tidak terdapat pengaruh antara komisaris independen terhadap net profit margin. Hal ini tidak sejalan dengan teori agensi yang menyatakan bahwa yang menyatakan bahwa dengan adanya komsiaris independen dapat memberikan fungsi pengawasan kepada perusahaan sehingga dapat mendukung kinerja perusahaan. Namun hal ini menunjukkan bahwa keberadaan dewan komisaris independen dilakukan hanya untuk pemenuhan regulasi, sehingga fungsi pengawasan yang seharusnya dilakukan dan menjadi tanggungjawab anggota dewan komisaris menjadi tidak efektif. Selain 
itu, masih terdapat perusahaan yang memiliki proporsi komisaris independen dibawah $30 \%$ sesuai dengan peraturan OJK.

\section{Pengaruh Kepemilikan Institusional Berpengaruh Terhadap Kinerja Keuangan}

Hasil pengujian hipotesis menjelaskan bahwa kepemilikan institusional memiliki pengaruh signifikan terhadap kinerja keuangan (NPM) sehingga hasil ini sama dengan hipotesis yang diajukan dalam penelitian ini. Hasil penelitian ini sejalan dengan teori agensi yang menyatakan bahwa dengan adanya kepemilikan institusional maka pengawasan terhadap perusahaan semakin baik sehingga dapat mengendalikan sikap oppurtunis manajemen. Hasil penelitian ini pun sejalan dengan penelitian yang dilakukan oleh Lestari \& Juliarto (2017) penelitian tersebut menghasilkan bahwa terdapat pengaruh signifikan positif antara kepemilikan institusional terhadap kinerja keuangan. Hal tersebut menunjukkan bahwa dengan adanya kepemilikan institusional dapat meningkatkan pengawasan terhadap manajemen agar manajemen berusaha meningkatkan kinerjanya sehingga tujuan perusahaan tercapai.

\section{Pengaruh Intellectual Capital Berpengaruh terhadap Kinerja Keuangan}

Hasil pengujian hipotesis menjelaskan bahwa Intellectual Capital tidak memiliki pengaruh signifikan terhadap Kinerja Keuangan (NPM) maka hasil ini tidak sama dengan hipotesis yang diajukan dalam penelitian ini. Dari hasil Uji T, Intellectual Capital memiliki koefisien regresi sebesar 0,586 dan nilai signifikansi sebesar 0,469. Hal ini menunjukkan bahwa variabel Intellectual Capital tidak berpengaruh signifikan pada tarif signifikansi 5\%. Dikarenakan hasil dari masing - masing komponen Intellectual Capital (MVAIC) perusahaan menghasilkan nilai yang kurang dan tidak sebanding dengan value added perusahaan yang lebih kecil.

\section{SIMPULAN}

Dewan Komisaris Independen (DKI) tidak memiliki pengaruh signifikan terhadap kinerja keuangan (NPM), Kepemilikan Institusional (INST) memiliki pengaruh signifikan terhadap kinerja keuangan (NPM) dan Intellectual Capital (MVAIC) tidak memiliki pengaruh signifikan terhadap kinerja keuangan (NPM), Hal ini dibuktikan dari hasil uji t yang telah dilakukan.

Penelitian ini mempunyai keterbatasan sebagai berikut: Pertama, Sampel penelitian ini hanya terbatas pada perusahaan Jasa Transportasi. Kedua, meneliti jangka pendek hanya 3 tahun. Ketiga, hanya menggunakan 1 alat ukur kinerja keuangan yaitu Net Profit Margin (NPM). Bagi Peneliti selanjutnya yang menggunakan penelitian yang sama disarankan untuk menambahkan jumlah sampel dengan sektor yang berbeda agar hasilnya lebih menyeluruh. 
INTELLECTUAL CAPITAL TERHADAP KINERJA KEUANGAN PERUSAHAAN

Penelitian selanjutnya juga diharapkan untuk menambahkan variabel-variabel lain selain yang sudah diteliti dalam penelitian ini.

\section{REFERENSI}

Aprianingsih, A., \& Yushita, A. N. (2016). Pengaruh Penerapan Good Corporate Governance, Struktur Kepemilikan, Dan Ukuran Perusahaan Terhadap Kinerja Keuangan Perbankan. Jurnal Profita, 4, 1-16.

Ariantini, I. G. A., Yuniarta, G. A., \& Sujana, E. (2017). Pengaruh Intellectual Capital, Corporate Social Responsibility, Dan Good Corporate Governance Terhadap Kinerja Perusahaan (Studi Kasus Pada Perusahaan Manufaktur Yang Terdaftar Di Bursa Efek Indonesia Tahun 2011-2015). E-Journal S1 Ak, 7(1).

Arifulsyah, H., \& Nurulita, S. (2020). Pengaruh Intellectual Capital Terhadap Kinerja Non Keuangan Perusahaan. Jurnal Akuntansi Keuangan Dan Bisnis, 13(1), 31-40. https://doi.org/10.31326/jks.v2i02.162

Budyastuti, T. (2018). Faktor- Faktor Yang Mempengaruhi Good Corporate Terhadap Manajemen Laba. Jurnal Manajemen Dan Akuntansi, 6, 70-88.

Dewi, A. S., Zusmawati, Z., \& Lova, N. H. (2018). Analisis Kinerja Keuangan dan Ukuran Perusahaan terhadap Harga Saham Perusahaan dalam Indeks LQ45 Di BEI dengan Regresi Data Panel. Jurnal Pundi, 2(2), 119-134. https://doi.org/10.31575/jp.v2i2.71

Dowling, J., \& Pfeffer, J. (1975). Pacific Sociological Association Organizational Legitimacy: Social Values and Organizational Behavior. Source: The Pacific Sociological Review, $18(1), 122-136$.

Elisetiawati, E., \& Artinah, B. (2016). Pengaruh Pelaksanaan Good Corporate Governance, Kepemilikan Institusional Dan Leverage Terhadap Kinerja Keuangan (Studi Pada Industri Perbankan Di Bursa Efek Indonesia). Jurnal Manajemen Dan Akuntansi, 17(April), 17-28.

Febriany, N. (2019). Pengaruh Intellectual Capital Terhadap Kinerja Keuangan Dan Pertumbuhan Perusahaan. Jurnal Ilmiah Akuntansi, XVII(1), 24-32. https://doi.org/10.17509/jrak.v3i2.6615

Ghozali, I. (2016). Aplikasi Analisis Multivariate dengan Program IBM SPSS 21 (viii). Badan Penerbit Universitas Diponegoro.

Gurdyanto, M. F. K. H. T., \& Anita, W. (2019). Pengaruh Corporate Governance Terhadap Kinerja Keuangan Perusahaan Manufaktur Sektor Industri Barang Konsumsi Sub Sektor Makanan Dan Minuman Di BEI. Research Fair Unisri, 3(1), 59-68.

Hasibuan, D. H., \& Sushanty, L. (2018). Pengaruh Good Corporate Governance Terhadap Kinerja Perusahaan Perbankan yang Terdaftar di Bursa Efek Indonesia Pada Periode 20132014. Jurnal Ilmiah Akuntansi Kesatuan, 6(1), 023-032. https://doi.org/10.37641/jiakes.v6i1.60

Jensen, M. C., \& Meckling, W. H. (1976). Theory Of The Firm: Managerial Behavior, Agency Costs And Ownership Structure. Journal of Financial Economics 3, 72(10), 1671-1696. 
Lestari, N. P., \& Juliarto, A. (2017). Pengaruh Dimensi Struktur Kepemilikan Terhadap Kinerja Perusahaan Manufaktur. Diponegoro Journal Of Accounting, 6(3), 1-10.

Lutfillah, N. Q., \& Sukmana, N. K. (2018). Modal Intelektual Sebagai Determinan Kinerja Perusahaan. Jurnal Akuntansi Kontemporer, 10(2), 56-68.

Nugroho, R. M., \& Widiasmara, A. (2019). Pengaruh dewan direksi berdasarkan gender, kepemilikan manajerial, kepemilikan institusional dan profitabilitas terhadap kinerja perusahaan perbankan periode 2015-2017. Prosdiing Unipma, 356-371.

Prayanthi, I., \& Laurens, C. N. (2020). Pengaruh Dewan Direksi, Komisaris Independen, Dan Komite Audit Terhadap Kinerja Keuangan Pada Sektor Makanan Dan Minuman. Klabat Journal of Management, 1(1), 66. https://doi.org/10.31154/kjm.v1i1.450.66-89

Pricilia, S., \& Susanto, L. (2017). Pengaruh Kepemilikan Institusional, Kepemilikan Manajerial, Komisaris Independen, Dan Ukuran Dewan Komisaris Terhadap Manajemen Laba Serta Implikasinya Terhadap Kinerja Keuangan Pada Perusahaan Manufaktur Yang Terdaftar di Bursa Efek Indonesia Periode 201. Jurnal Ekonomi, 22(2), 267-285. https://doi.org/10.24912/je.v22i2.226

Puspitasari, F., \& Ernawati, E. (2010). Pengaruh Mekanisme Corporate Governance terhadap Kinerja Keuangan Badan Usaha. Jurnal Manajemen Teori Dan Terapan, 3(2), 189-215.

Puspitosari, I. (2016). Pengaruh Modal Intelektual terhadap Kinerja Keuangan pada Sektor Perbankan The Impact of Intellectual Capital on Banking Sectors Financial Performance. Lp3M Stiebbank, 7(1), 43-53.

Putra, R. H., \& Fidiana. (2017). Pengaruh Tata Kelola Perusahaan terhadap Kinerja Keuangan Perusahaan. Jurnal Ilmu Dan Riset Akuntansi, 6(8), 1-17.

Putri, S. D., \& Nuzula, N. F. (2019). Pengaruh Intellectual Capital Terhadap Kinerja Keuangan dan Nilai Perusahaan (Studi pada Perusahaan Sektor Manufaktur Yang Terdaftar di Bursa Efek Indonesia Periode 2012-2017). Jurnal Administrasi Bisnis, 66(1), 28-36.

Roos, G., \& Roos, J. (1997). Measuring your Company 's Intellectual Performance. 30(3), 413-426.

Ruslim, H., \& Santoso, I. (2018). Pengaruh Proporsi Komisaris Independen , Jumlah Direktur , Jumlah Komite Audit, Kepemilikan Saham Institusional, Kepemilikan Saham Manajemen Dan Ukuran Perusahaan Terhadap Kinerja Keuangan Perusahaan. Jurnal Ekonomi, XXIII(03), 334-346.

Sriwahyuni, D., Hermawan, S., \& Hanun, N. R. (2019). Intellectual Capital Terhadap Kinerja Keuangan Perusahaan Farmasi Di Indonesia. EBA Journal: Journal Economics, Bussines and Accounting, 5(1), 31-38. https://doi.org/10.32492/eba.v5i1.709

Sugiyono. (2014). Metode Penelitian Kuantitatif, Kualitatif dan Kombinasi. Alfabeta: Bandung.

Ulum, D. I. (2017). INTELLECTUAL CAPITAL: Model Pengukuran, Framework Pengungkapan \& Kinerja Organisasi (S. R (ed.); Ketiga, pp. 1-257). Penerbit Universitas Muhammadiyah Malang. 
PENGARUH DEWAN KOMISARIS INDEPENDEN, KEPEMILIKAN INSTITUSIONAL DAN

INTELLECTUAL CAPITAL TERHADAP KINERJA KEUANGAN PERUSAHAAN

Ulum MD, I. (2009). Intellectual Capital (Kedua, pp. 1-163). Graha Ilmu, Yogyakarta.

https://investasi.kontan.co.id

https://properti.kompas.com

https://finance.detik.com

www.idx.co.id 